\title{
The floating community of Muslims in the island city of Guangzhou
}

\author{
Ping Su \\ Sun Yat-sen University, Zhuhai, China \\ suping1983@gmail.com
}

\begin{abstract}
The paper explores how Guangzhou's urban density and hub functions have conditioned its cultural dynamics by looking specifically at the city's Muslim community. Guangzhou's island spatiality has influenced the development of the city's Muslim community both historically and in the contemporary era. As a historic island port city, Guangzhou has a long-standing tradition of commerce and foreign trade, which brought to the city the first group of Muslims in China. During the Tang and Song dynasties, a large Muslim community lived in the fanfang of Guangzhou, a residential unit designated by the government for foreigners. Later, in the Ming and Qing dynasties, Hui Muslims from northern China, who were mostly soldiers, joined foreign Muslims in Guangzhou to form an extended community. However, during the Cultural Revolution, Guangzhou's Muslim community and Islamic culture underwent severe damage. It was not until China's period of reform and opening-up that the Muslim community in Guangzhou started to revive, thanks to the city's rapid economic development, especially in foreign trade. This is today a floating community, lacking geographical, racial, ethnic, and national boundaries. This paper argues that Guangzhou's island spatiality as a major port at the mouth of the Pearl River has given rise to a floating Muslim community.
\end{abstract}

Keywords: floating community, Guangzhou, island cities, Muslims, trading port, spatiality

https://doi.org/10.24043/isj.18

(C) 2017 - Institute of Island Studies, University of Prince Edward Island, Canada.

\section{Introduction}

Guangzhou, an archipelagic port city located in the Pearl River Delta and the capital of Guangdong Province, is one of China's ten largest and most densely populated cities. It hosts the biannual China Import and Export Fair (Canton Fair), the oldest and largest trade fair in China. Vast quantities of electronics, toys, clothing, and plastic goods are shipped from the city all over the world. As a mighty manufacturing hub and major centre for international trade, Guangzhou has attracted not only millions of migrants from other parts of China, but also a large number of foreigners from over 150 countries who come to work and live in the city (广州市来穗人员服务管理局, 2016). The numerous islands of Guangzhou are today linked to one another and to the mainland by bridges or tunnels and in some cases even joined together by the construction of new ground. It can nevertheless be useful to analyze even highly connected cities like Guangzhou from an island perspective since "the historical topography and island spatiality of these cities has often strongly conditioned their future development" (Grydehøj et al., 2015, p. 6).

Along with its economic boom, Guangzhou's dynamic culture has drawn increasing attention. As the cultural hub of South China, the city has a multicultural flavour, filled with people of various skin colours, nationalities and religious beliefs. Guangzhou has, in fact, a long-standing tradition of multicultural openness. Having been the starting port on the Maritime Silk Road trade route since the 3rd century BCE, it was an important trading port and the southern gateway of ancient China (张难生, 叶显恩, 1992, p. 208). During the Tang Dynasty (618-907 CE) and Song Dynasty 
(960-1279 CE), Guangzhou became China's biggest port, and, during the Ming Dynasty (1368-1644 CE) and Qing Dynasty (1644-1912 CE), it was the only port that was consistently open to foreign trade (蔡穗声, 1991, p. 1). Between 1757 and 1842, before the unequal treaties between China and foreign imperialist powers opened many other port cities, it was the only Chinese city where foreign merchants were allowed to live and work (杨万秀, 钟卓安, 2015, p. 152). During the Cultural Revolution (1966-1976), China's legal foreign trade was almost solely composed of the deals negotiated at the biannual trade fairs held in Guangzhou (Roy, 1998, p. 82).

The city is thus known as a millennium-old trading port. As Swaminathan (2015) notes, old port cities - as traditional contact sites between the overseas and the mainland, the foreign and the domestic - are particularly prone to develop into sites for other kinds of cultural and economic exchange as well. Throughout its vibrant history, Guangzhou, serving as a vital channel of communication between China and the rest of the world, has absorbed exotic cultures from both east and west. And although the major cultural form of Guangzhou is Cantonese culture, various cultural forms have co-existed there, including domestic cultures from the rest of China and far-flung foreign cultures from overseas. These different cultures interact and cross-fertilize with each other, contributing to the dynamism and openness of the city.

The cultural dynamics of Guangzhou are most explicitly reflected in its religions. The city has historically hosted numerous religions, including China's native religion Taoism and such world religions as Islam, Buddhism, Christianity, Judaism, and Zoroastrianism. Taoism and Buddhism are the earliest known religions introduced to Guangzhou (杨鹤书, 1986). Yet, according to contemporary Arab accounts, Ancient Account of India and China (穆根来, 汶江，黄倬汉, 1983, p. 96) and The Meadow of Gold and Mines of Gems (马苏第, 1998, pp. 180-1), the total number of Muslims, Christians, Jews, and Zoroastrians in Guangzhou had reached over 120,000 by the 9th century. Many temples, mosques, and churches built in ancient times are now important historical and cultural heritage sites under special protection, such as Liurong Buddhist Temple, Sanyuan Taoist Temple, Huaisheng Mosque, and Sacred Heart Cathedral, to name just a few. Guangzhou's strong development in business and trade has enriched the composition of the city's religious followers because merchants and businessmen of various religious beliefs have come in large numbers to trade in the city.

In 1978, when China began its period of reform, Guangzhou became among the first places (along with 13 other port cities) to open up to the world and implement many experimental policies, which further enhanced its reputation as a trading centre. After nearly 40 years of social and economic reform, Guangzhou is now among the most economically developed areas in China. The city, having attracted billions of dollars in foreign investment, is home to thousands of shops, factories, and hotelslarge and small — that have benefited from foreign investment. Still functioning as a bridge between China and the world, and close to the Special Administrative Regions of Hong Kong and Macau, Guangzhou has been further exposed to foreign cultures and become one of China's most culturally dynamic places. Because of its rapid economic development and vibrant cultural environment, Guangzhou is full of opportunities for both locals and outsiders and has drawn millions of migrants (including internal and international migrants). As a result, the city's 'floating population' exceeds its permanent population (广州市来穗人员服务管理局, 2015). The liudong renkou 流动人口 (floating population) concept is unique to China and related to the hukou 户口 system of household registration: people who do not live at their hukou sites are regarded as 'floating'. Among these migrants are a large number of Muslims, including both Chinese Muslims, mostly from China's western provinces, and foreign Muslims from the Middle East, Africa, South Asia, and Southeast Asia.

In other words, Guangzhou has risen, grown, and flourished on the basis of commerce and trade, which has been conditioned by its geographical status as an island port city. Its economic prosperity has in turn contributed to its rich and vibrant cultures. This paper explores how Guangzhou's urban density and hub functions - encouraged by island spatiality-have conditioned the city's cultural dynamics by looking specifically at its floating Muslim community in both historical and contemporary contexts. 


\section{History of the Muslim community in Guangzhou}

The history of the Muslim community in Guangzhou is closely associated with the city's status as an island port city. As Grydehøj (2015, p. 429) puts it, "the beneficial aspects of island spatiality (including territoriality, defence and transport) make islands favourable sites for establishing certain kinds of settlements." These spatial benefits have made Guangzhou a city of historical, political, economic, and cultural significance. The city first appeared in the history of China when Panyu (an old name for Guangzhou) was established on the east bank of the Pearl River in 214 BCE (杨万秀，钟卓安, 2015, p. 15). The city's exceptional territoriality and defensibility contributed to its serving as the capital of the three ancient kingdoms of Nanyue 南越 (204-111 BCE), Nanhan 南汉 (917-971 CE), and Nanming 南明 (1646-1647 CE), as well as the seat of provincial and prefectural government during most of China's dynasties. Even more important, however, are Guangzhou's transport benefits, which have determined its special position as the centre of South China's economy, trade, culture, and transportation to this day. As Grydehøj (2015, p. 432) notes, estuary islands such as those of Guangzhou have been "particularly valuable as easily administrable and defensible interfaces between sea and mainland supply routes." Indeed, over time, the Pearl River Delta's various clusters of islands would give rise to important island cities not only in Guangzhou but also in Hong Kong and Zhongshan Dao (including today's Zhongshan, Zhuhai, and Macau). Guangzhou has been a major international trading port for over a thousand years, and the discovery of the remains of a Qin Dynasty (221-207 BCE) shipyard in Guangzhou in 1975 suggests that the city was probably already trading frequently with foreigners through sea routes as far back as the 3rd century BCE (广东省文物局, 2016, p. 63).

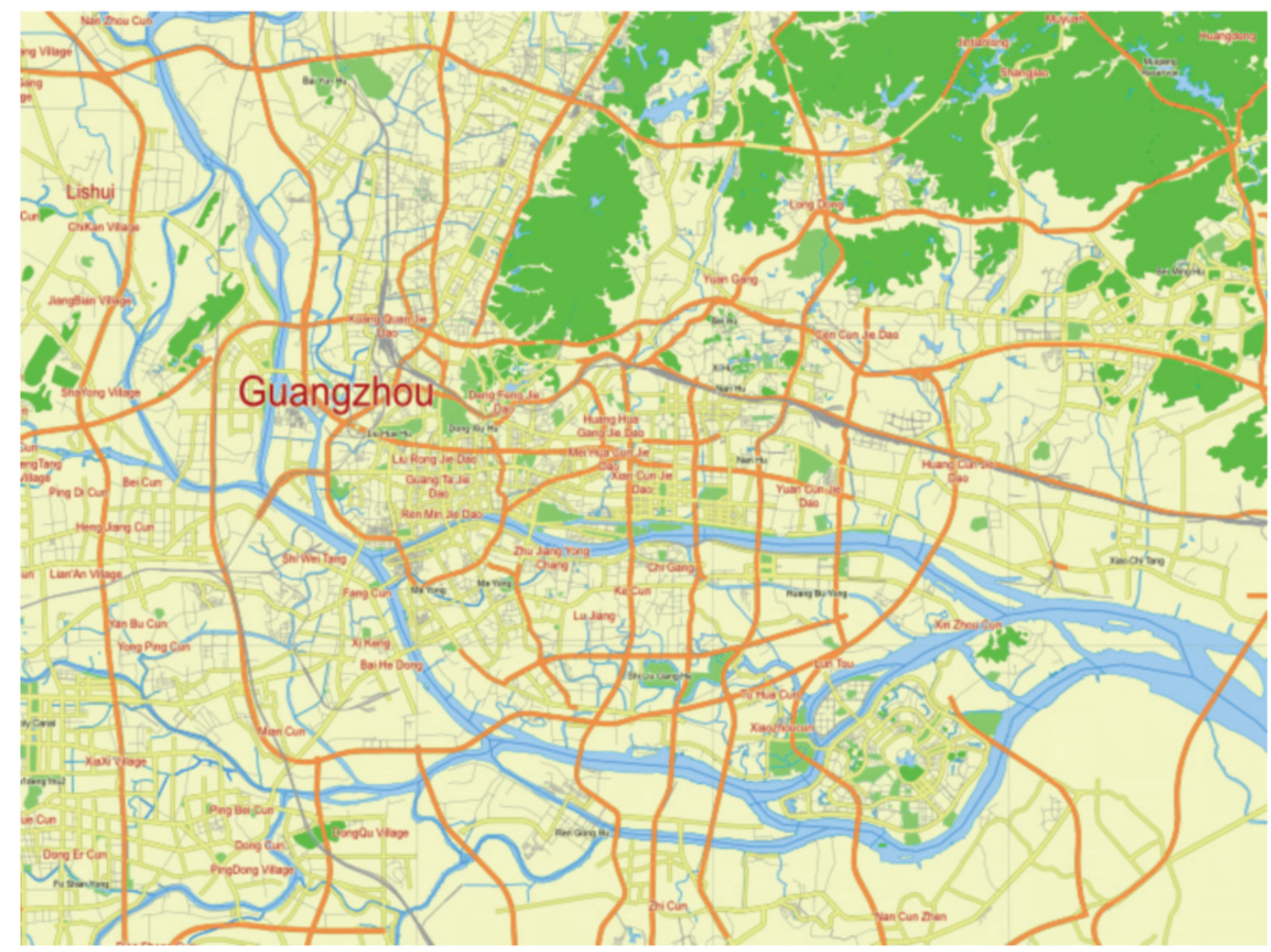

Figure 1: Map of Guangzhou. (C) Ilya Shrayber, 2016, https://commons.wikimedia.org/wiki/File:Guangzhou_city_map_plan_China_Level_12_English.svg) 
Arab traders were among the earliest foreigners who are known to have come to trade in Guangzhou. In 610 CE, the Islamic prophet Muhammad began to receive revelations from Allah, which marks the start of Islam. Muhammad then started spreading the messages amongst the people. By the time of his death in $632 \mathrm{CE}$, most of the Arabian Peninsula had converted to Islam. Muslim traders from Arab countries brought Islam to China soon after its founding. Guangzhou, as a major trade centre, saw the arrival of the first Muslims in China in the early 7th century, during the Tang Dynasty. According to old Chinese Muslim manuscripts, Saad ibn Abi Waqqas, an uncle of Muhammad, built Huaisheng Mosque - the first in China-in Guangzhou in 627 CE to commemorate the Islamic prophet (Lipman, 1997, p. 29). Since the Tang Dynasty, there have been many Arab Muslims living in Guangzhou, engaged in trade or business.

According to Grydehøj (2015, p. 432), local authorities in China usually preferred that "foreign traders be restricted to small islands" because the territorial and defense benefits of island spatiality would make it easy to contain "the spread of their political influence" and prevent "confusion in the allocation of territoriality," which made Guangzhou an ideal place "for hosting trade visits by foreigners." These foreign traders were required by the imperial Chinese government to live in a certain allocated area, known as the fanfang 蕃坊 (foreigners' quarters) during the Tang and Song dynasties. The fanfang of Guangzhou was located in the west of the city, separated from the other islands of the city by river channels. The foreigners who lived there were of various ethnicities, cultures, languages, races, and religions. They were permitted to follow their own customs and religious beliefs as well as buy land and residences in this neighbourhood. The fanfang was of political importance for the Chinese government: it separated Chinese from foreigners; obviated their conflicts; was convenient for commerce; and, most importantly, prevented foreigners from forming a threatening power.

Most of the foreigners living in the fanfang were Muslim traders. Though they were of various nationalities, they identified with each other due to their shared religious beliefs and formed China's earliest Muslim community. The special geography of the fanfang, forming a separate society with water boundaries, not only insulated the Chinese from foreign influence but also helped protect and sustain the Muslim community's own culture and traditions. This highlights the ambiguous dual function of urban island spatiality: protecting the island from the demands of the city and the city from the demands of the island (Grydehøj, 2014, p. 187). Muslims, enjoying complete religious tolerance, could attend religious services in Huaisheng Mosque, which was located within the fanfang. Being confined within this foreign quarter, the Chinese government did not regard Islam as a potential challenge. For instance, when Buddhism and other foreign religions that had made inroads among the Chinese population were crushed in $845 \mathrm{CE}$, Islam was not listed as a target of suppression (李兴华，冯今源，秦惠涁，沙秋真，1998, p. 46).

Although Muslims came to live and trade in Guangzhou as early as the 7th century, their integration into the city's collective consciousness was a gradual and slow process. In the Tang and Song Dynasties, many Muslim traders learned the Chinese language, acquired Chinese names, and studied Confucianism, finding it to be compatible with the teachings of Islam. Some intermarried with the Chinese or even sat for imperial examinations to gain government appointments. For instance, Li Yansheng (李彦升), an Arab living in Guangzhou, obtained the jinshi 进士 (advanced scholar) degree in $848 \mathrm{CE}$ and became a distinguished official (Jian \& Ma, 2011, p. 205). The influence of Chinese culture on the early Muslim community in Guangzhou was also shown in the fact that Huaisheng Mosque, built in the Tang Dynasty, followed the traditional Chinese architectural style used in Buddhist and Confucian temples (李荣珍, 2006, p. 35). However, until the mid-Song Dynasty, almost all Muslims in China, called fanke (蕃客, foreign sojourners), "considered themselves, and were considered by the Chinese, to be temporary residents rather than permanent settlers" and "neither they nor the Chinese state desired their acculturation or assimilation" (Lipman, 1997, pp. 28-9). Moreover, Muslim sojourners in Guangzhou, whose activities were limited within the fanfang, seldom interacted with the locals. 


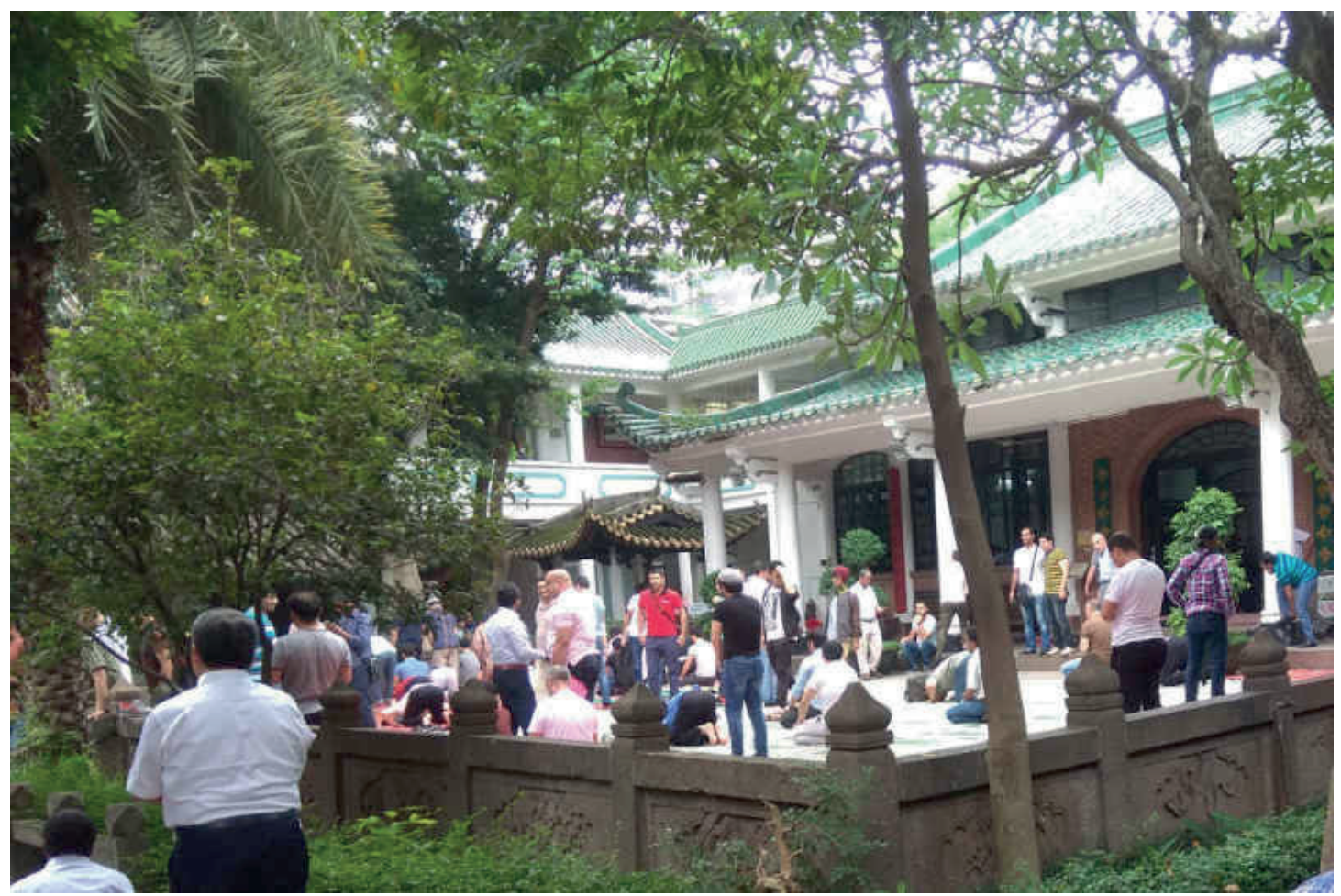

Figure 2: Huaisheng Mosque. (C) Ping Su).

In the Yuan Dynasty (1271-1368 CE), when the Mongol conquerors brought to China an influx of Muslims of various professions and cultures, the Muslim community in Guangzhou actually shrank for two reasons: firstly, most of the Muslims who arrived in China in this period did so through the overland Silk Road, and virtually all stayed in northern or western China; secondly, Quanzhou replaced Guangzhou as China's foremost port on the Maritime Silk Road trade route, thereby attracting most of the Muslims who arrived by sea (李兴华, 2011, p. 79). Therefore, despite the fact that, by the late Song Dynasty, some Muslims were included among tushengfanke 土生蕃客 (native-born foreign sojourners) or wushi fanke 五世蕃客 (fifth-generation foreign sojourners) and had already been living in Guangzhou for many generations, their integration into Chinese society did not start until the Ming Dynasty. It was then that Muslims were first referred to as 'Chinese Muslims' or 'Muslim Chinese', rather than as 'Muslims in China' (Leslie, 1998, p. 14).

During the lengthy Ming and Qing Dynasties, China banned maritime trade to consolidate internal control and avoid external attack. Although Guangzhou was still open to foreign merchants, the government implemented strict rules to limit and constrain foreign trade, greatly reducing the number of Muslim merchants arriving in the city. However, the city's Muslim community continued to grow due to the many Hui Muslim soldiers who were sent to Guangzhou by the Ming and Qing governments to suppress revolts and perform garrison duties. These Muslim soldiers were encouraged by the governments to intermarry with the Han Chinese, which was opposite to the Tang and Song restrictions on intermarriage (李兴华, 2011, p. 82). The residential area of the Muslim soldiers and their families was extended from the single unit - the fanfang of the Tang and Song Dynasties - to multiple units built around military camps. They constructed mosques and other places of worship within these units, forming sub-communities with clear geographical boundaries. All of the extant mosques in Guangzhou, with the exception of Huaisheng Mosque and Xianxian Mosque, were built in the Ming and Qing Dynasties.

Apart from the soldiers, however, other Muslims in the city at that time- such as merchants, missionaries, imams, and refugees-were concentrated and formed a sub-community around Huaisheng Mosque. Despite its expansion beyond the area it covered in the Tang and Song 
Dynasties, the Muslim community in the Ming and Qing Dynasties was still largely defined by its geographical borders. Yet in this period, with Islam being viewed by the Chinese as "amenable and willing to accommodate to Confucianism" (Leslie, 1998, p. 15), Muslims in Guangzhou, whose "ties with the Muslim world outside China had been completely severed" (Lipman, 1997, p. 46), began to be integrated into society. They spoke Cantonese like their non-Muslim neighbours, participated in Chinese culture, and acculturated in many spheres of daily life. Regarding China as their homeland and its politics as their own, they were loyal to the dynasties (李兴华, 2011, p. 82) and later developed into what is now considered the local Hui 回族 ethnic group of Guangzhou. The Communist Government defines the Hui ethnic group as encompassing all historically Muslim communities not covered by the other ethnic groups of China (Gladney, 1996, p. 20).

In the late 19th century, when China was plagued by foreign invasions, the concept of 'nation' entered the mind of Chinese intellectuals who thus made great efforts to construct a Chinese nation and promote Chinese nationalism (郑师渠, 1995, pp. 90-1). In his book Imagined Communities, Benedict Anderson (1991, pp. 6-7) defines 'nation' as an imagined political community where its members live with "the image of their communion" with each other even though they "will never know most of their fellow-members." Throughout the 20th century, the idea of nation figured continuously in China's political discourse. Both the Kuomintang and the Chinese Communist Party used nationalism as an important political tool. To unite a heterogeneous population, they promoted the image of the plural singularity of the Zhonghuaminzu 中华民族 (Chinese nation) and integrated ethnic minorities into this imagined community (郑大华, 2013, p. 10). The foreign threats faced by China in this period further enhanced such a collective consciousness as the shared experience of suffering and enduring harsh times together can strengthen a sense of communion. Intimate with their native land, Muslims of Guangzhou, a city called the cradle of China's modern revolution (高惠冰, 2006, p. 21), exhibited strong patriotism and participated actively in all major political campaigns, such as the anti-Japanese war, the national liberation war, and the construction of new China.

Yet the Cultural Revolution, which aimed to bring an end to the Four Olds (that is, Old Customs, Old Culture, Old Habits, and Old Ideas), nearly destroyed the Muslim community in Guangzhou. The mosques were seriously damaged, and all religious activities ceased. Muslim communities were split up, and Muslims were sent to work in the countryside or in factories, where they had to eat together with non-Muslims in the dining hall. Surrounded by Han people, many Muslims ended up marrying non-Muslims, who did not themselves convert to Islam. As a result, the local Hui Muslims of Guangzhou were almost completely assimilated into the dominant Han culture. After the Cultural Revolution, the government granted more freedom of religion, the mosques were reconstructed, and various religious activities were resumed in Guangzhou, initiating a revival of Islamic culture. Yet, in the late 1970s and the 1980s, the Muslims in Guangzhou were still mainly composed of the local Hui ethnic group, which had been scattered around the city and had lost many of its members, who had become non-believers. The revival of Islamic culture had not yet gained momentum during this period, a situation that only started to change in the last decade of the 20th century.

The above review of the history of Guangzhou's Muslim community shows that its formation, growth, and development were based on the city's special position as China's most important port for foreign trade throughout history, a status that was conditioned by Guangzhou's island spatiality. 


\section{The formation of a floating community}

In social science, 'community' is a highly complex concept. Community is often defined in geographical terms, a tendency that, given the easy conceptualization of island spaces as distinct geographical units (Baldacchino, 2012), is perhaps particularly prevalent in island research (Ronström, 2012, p. 155). As Philip Hayward (2012, p. 1) notes of traditional approaches to understanding islanders: "Island communities [...] are innately linked to and dependent on finite terrestrial resources and constantly react to and work within the transitional zone between land and sea." Yet some scholars, such as Barry Wellman (1979) and Benedict Anderson (1991), argue that conceptualizations of community must be liberated from locality and direct social interaction. Others, such as David B. Clark (1977) and M. Scott Peck (1988), emphasize the spiritual meaning of community. The Muslim community of present-day Guangzhou, an "imagined religious community" in Anderson's terminology (1991, p. 56), has broken away from the exclusivity of locality and extended beyond the boundaries of ethnicity, race, and nationality. Morever, Guangzhou's Muslim community no longer possesses spatial boundaries (the island fanfang) but is instead bound by spirituality through religion. The community is thus translocal, pluralistic, and 'floating'.

My knowledge of Guangzhou's Muslim community today is based on fieldwork that I have been conducting in the city since 2014. Personal conversations with numerous Muslims from various parts of the world have been carried out in the process. I call this community a floating one in this paper for two reasons: first, its members mostly belong to the 'floating population' whose stay is only temporary; second, the community is not restricted to a fixed neighbourhood or residence, but floats across times and locations. Nevertheless, it remains an effective community as its members are linked by their religious beliefs and values which, according to the noted sociologist James S. Coleman (1976, p. 559), could help define a community.

Although the development of the floating Muslim community is no longer predominantly conditioned by Guangzhou's internal archipelagic spatiality, it continues to be conditioned by the city's overall island status with reference to its hinterlands in Guangdong and farther afield. In 1957, in an effort to break an economic blockade imposed by western countries, the Chinese government selected Guangzhou as the site for the Chinese Export Commodities Fair (renamed the China Import and Export Fair in 2007) because the city, a major trading port for centuries, is close to Hong Kong and Macau (then British and Portuguese colonies respectively), while its territoriality would help contain the so-called corrosive influences of capitalist ideology. Later, in the early stage of China's reform and opening-up period, Guangzhou was selected as among the first places open to foreign business, and new policies were implemented to encourage overseas investment. Since then, Guangzhou's economy has developed rapidly, significantly as a result of the city's territoriality and transport benefits but also as a result of the continued "agglomeration economies" that Grydehøj (2015, p. 433) identifies as "the most important benefit arising from urban density" in island cities. As an estuary island port and a transport hub in South China, Guangzhou provides convenient transportation through which goods can be easily transferred from the mainland and shipped out to other countries. Guangzhou's foreign trade volume has increased at an unprecedentedly high speed since its opening-up while prosperous foreign trade and increased overseas investment in the city have in turn further stimulated its manufacturing industry and economic growth. This process has attracted an increasing number of Muslims-both Chinese and foreign - who wish to work or do business in the city.

In the 1990s, with the deepening of reform, many Muslims of various ethnic, national, and socio-economic backgrounds came to Guangzhou to seek jobs or engage in trade. These Muslim migrants include Uyghur people from China's Xinjiang Province; Hui people from Northwestern Chinese provinces such as Ningxia, Gansu, and Shaanxi; Arabs from the Middle East; black Muslims from Africa; and Muslims from South Asia and Southeast Asia. The number of Muslims in Guangzhou, increasing year by year, reached 120,000 by 2016 , among which almost half are 
foreign Muslims (广东省民族宗教事务委员会, 2016). Unlike the Muslims of former times, who lived exclusively in particular islanded neighbourhoods and in the vicinity of mosques, these newcomers have chosen to live in commercial districts, in areas with convenient transport opportunities, near Muslim restaurants, or in inexpensive districts such as chengzhongcun (城中村, urban villages: former agricultural settlements that have been enveloped by the city in the process of rapid urbanization; see Wang \& Zheng, 2013, p. 321). Although scattered across the city, today's Muslims of Guangzhou have formed a new type of international Muslim community: a floating community that lacks fixed geographical or ethnic boundaries but is instead bound by a shared religion. Mosques and Muslim markets, shops, companies, and restaurants, located predominantly in the Yuexiu District (Guangzhou's commercial and financial centre as well as the site of provincial and municipal government headquarters), have thus become contact zones in which Muslims of various ethnicities, cultures, languages, and nationalities interact with each other, forming a kind of floating spiritual community in this process.

Although Muslims usually prefer to live near mosques, the high proportion of (domestic and international) migrants among Guangzhou's Muslims means that they usually choose their place of residence on the basis of its price or convenience for work. Yet mosques still play an important role in strengthening the community's sense of solidarity and cohesion. Even though most Muslims in Guangzhou conduct salāh (often translated as 'prayer', the word in Islam refers to a physical, mental, and spiritual act of worship, which Muslims observe five times every day within the prescribed hours) at home or in their workplaces because the mosques (all in the Yuexiu District) are located quite a distance away, they often manage to go to the mosques for Jumu'ah (a congregational prayer held at noon on Fridays) and for the two main Muslim festivals, Eid al-Fitr (the Festival of Fast-Breaking) and Eid al-Adha (the Festival of Sacrifice). During these times, the mosques are crowded with Muslims of different races and ethnicities, who are led in prayer by a single imam.

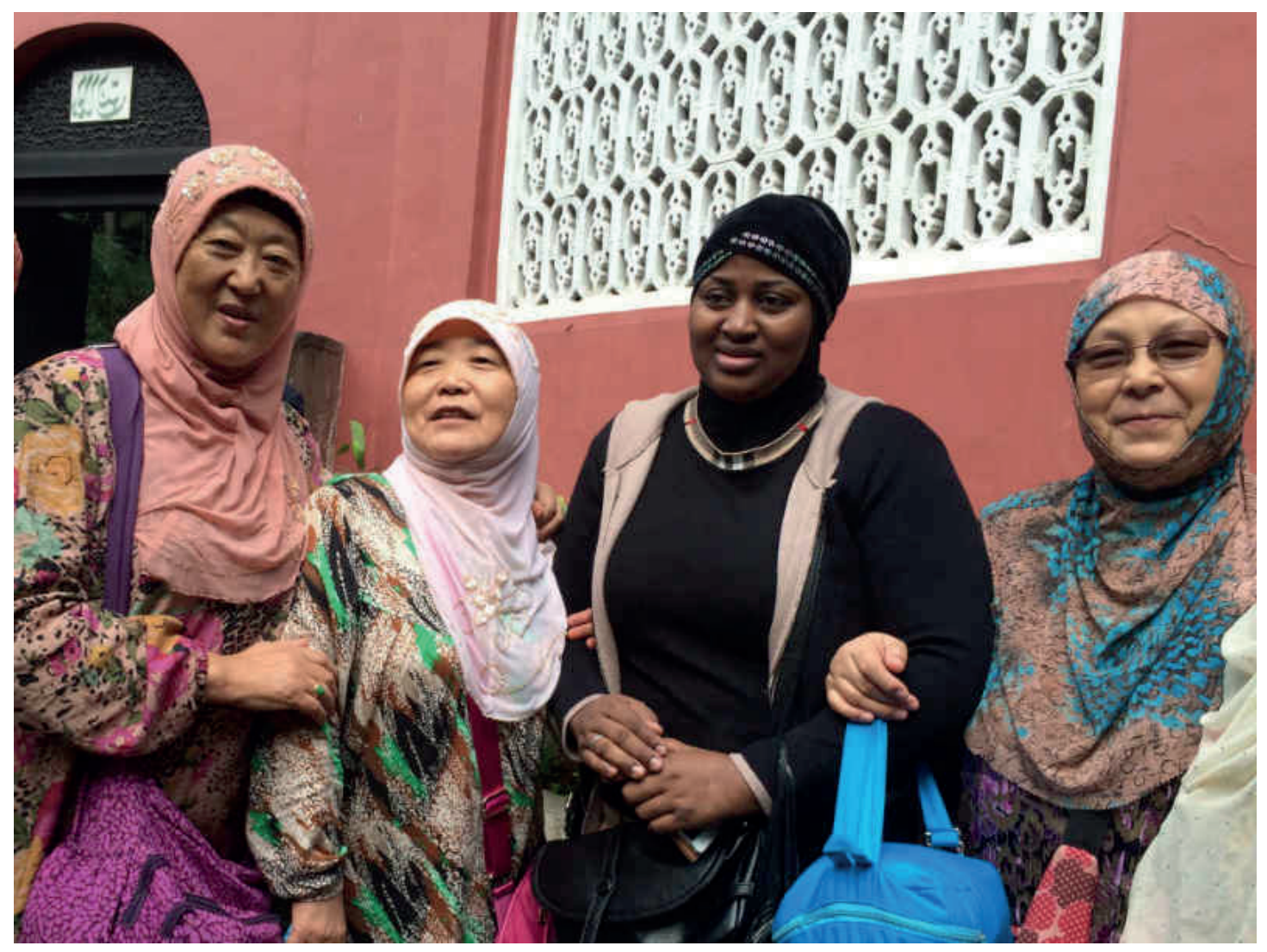

Figure 3: Xianxian Mosque. (C) Ping Su) 
The number of Guangzhou Muslims attending prayers in mosques usually rises sharply during the month of Ramadan. After the congregational prayer, some Muslims, including both Chinese and foreign ones, make use of the opportunity to distribute food or donate money to the mosques. Misunderstandings sometimes arise between Chinese and foreign Muslims due to differing customs, as Mr. Ma indicates during an interview:

Some Chinese Muslims, particularly Hui Muslims from Gansu and Ningxia, like to burn incense when they go to pray in the mosques. This practice is closely related to the influence of the traditional Chinese culture and the other religions in China such as Buddhism and Taoism. But Muslims from other countries never do this. I remember once I went to perform the Friday prayer at Xianxian Mosque and saw some African Muslims were quarreling with several Chinese Muslims who were burning incense in the mosque because they thought these Chinese Muslims were actually Buddhists and felt offended by the action of burning incense. Yet after some discussion, they were able to understand and accept that this is a special custom of Chinese Muslims. There are also slight differences in how to undertake salāh among Muslims from different parts of the world, but in the mosques, we will all follow the customs of Guangzhou Muslims and do as the imams do. The local imams, on the other hand, have made some changes to the way of praying according to the customs of foreign Muslims. (Excerpt from a personal conversation with Mr. Ma, a Chinese Muslim of the Hui ethnic group and a colleague of mine at Sun Yat-sen University, conducted on 11 January 2016.)

It is through these minor conflicts and cultural interactions that Muslims in Guangzhou become more tolerant and open-minded. The mosques, remaining as spiritual centres for Muslims living in the city, help give form to the floating Muslim community, thereby providing a space in which Muslims dispersed across the city can meet, communicate, and interact.

Muslim markets and shops are also significant in sustaining the floating community. Because Muslims can only eat halal foods in accordance with Islamic dietary guidelines, they usually buy food from Muslim markets and shops. For instance, in Xiaobeilu, a Guangzhou neighbourhood locally known as 'Little Africa', there are many Muslim shops and markets. Numerous Muslims, even those who live at a considerable distance in neighbouring cities such as Zhuhai and Foshan, will visit Xiaobeilu regularly to buy food:

I live in Zhuhai, but I go to Xiaobeilu in Guangzhou each weekend to buy food for a whole week, because I do not trust the halal foods sold in other places. We have only one Muslim restaurant on our campus, and the food sold there is not very good, so when I am too busy to cook myself, I simply eat the readymade food I have bought in Xiaobeilu. (Excerpt from a personal conversation with Ms. Zhou, a Chinese Muslim of the Hui ethnic group and a colleague of mine at Sun Yat-sen University, conducted on 10 December 2015.)

For convenience, many Muslims of various ethnicities choose to live or work in Xiaobeilu as well. Therefore, the streets of this neighbourhood are filled with Arab, Uyghur, Hui, and African Muslims, as well as Muslims from other parts of the world. This 'Little Africa' neighbourhood is thus more of a 'Little Islamic World'. It also helps form the floating Muslim community by maintaining network relationships not only between those who live and work there but also between those who visit regularly for shopping. The markets and shops in Xiaobeilu thus become places that gather Muslims of various origins together and create a bond between them. For example, although most of Xiaobeilu's halal butcher shops are run by Hui Muslims, their customers include Muslims of other ethnicities as well: 
Ping Su

I trust the shop owners here because they are Muslims themselves. I believe the meat they sell is real halal food. I don't have to bargain with them or worry about being tricked. I am safe in the knowledge that, being Muslims, the shop owners will not give short measure or charge a high price because these dishonesties are not allowed by Allah. (Excerpt of a personal conversation with Syrian businessman Abdul Rahman, conducted on 26 November 2015.)

This conversation with Abdul Rahman indicates a mutual trust between Muslim customers and shop owners. This trust is based on shared religion rather than shared nationality, ethnic background, or place of origin.

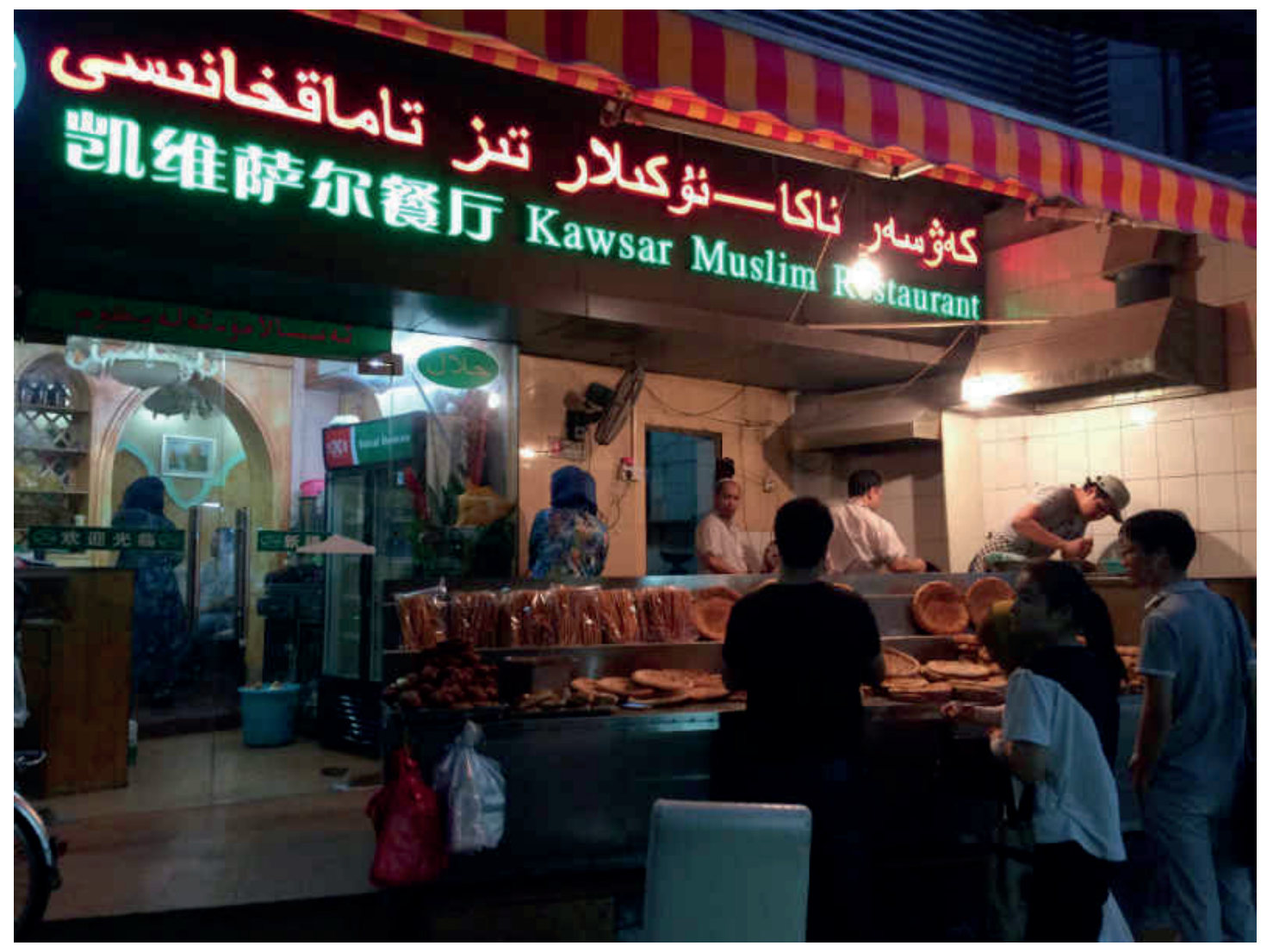

Figure 4: Halal restaurant in Xiaobeilu. (C) Ping Su)

As stated above, Muslims migrate to Guangzhou either to get a job or for business. Most foreign Muslims in the city are businessmen who have established companies of various sizes, while Muslims from other provinces of China come to Guangzhou mainly to work as translators, salespeople, or vendors, or to run small shops or restaurants. The Muslim companies, when recruiting employees, usually prefer Muslim applicants as it is believed that better understanding and communication can be achieved among Muslim staff members. The majority of employees in companies owned by foreign Muslims are thus Hui Muslims from across China, and in big companies, Muslims of various nationalities often work together:

I worked as an intern at an Arab company this winter. There are many other Arab companies in the same building. I noticed that most of the translators who do translation between Arabic and Chinese for Arab companies are Hui Muslims since they make up the majority of people who are fluent in both Arabic and Mandarin. These translators work as intermediaries between Chinese and Arab companies, helping foreign Muslims 
import products from the Guangzhou market. Quite often, the services they provide go far beyond translation. They will investigate the prices, ask for samples, place orders, pack and ship the goods. They also function as bridges and windows for foreign Muslims to understand China because many Muslims from other countries learn about Chinese politics, economy, and culture through those translators who work at the same company with them. When they have any difficulties in life, such as how to open a bank account and how to find a certain place, they will seek help from those translators who are not only their colleagues or staff members but also their friends. Chinese Muslims working at these companies will also know about the customs, cultures and situations of Muslims in other countries from their foreign colleagues. Muslims at the same company usually conduct salāh together in their workplace. Sometimes Muslims working at different companies in the same office building will gather together to pray at one company or at a certain place in the building. (Excerpt from a personal conversation with Chen, a Hui Muslim student at Sun Yat-sen University, conducted on 24 February 2016.)

Apart from being places for Muslims of different skin colours to work together, Muslim companies also provide space for them to exchange their ideas and cultures with each other. Interactions between different Muslims at a same company are carried out on a spiritual level as well. Therefore, it can be said that Muslim companies in Guangzhou play an important role in promoting a sense of community among Muslims of different origins.

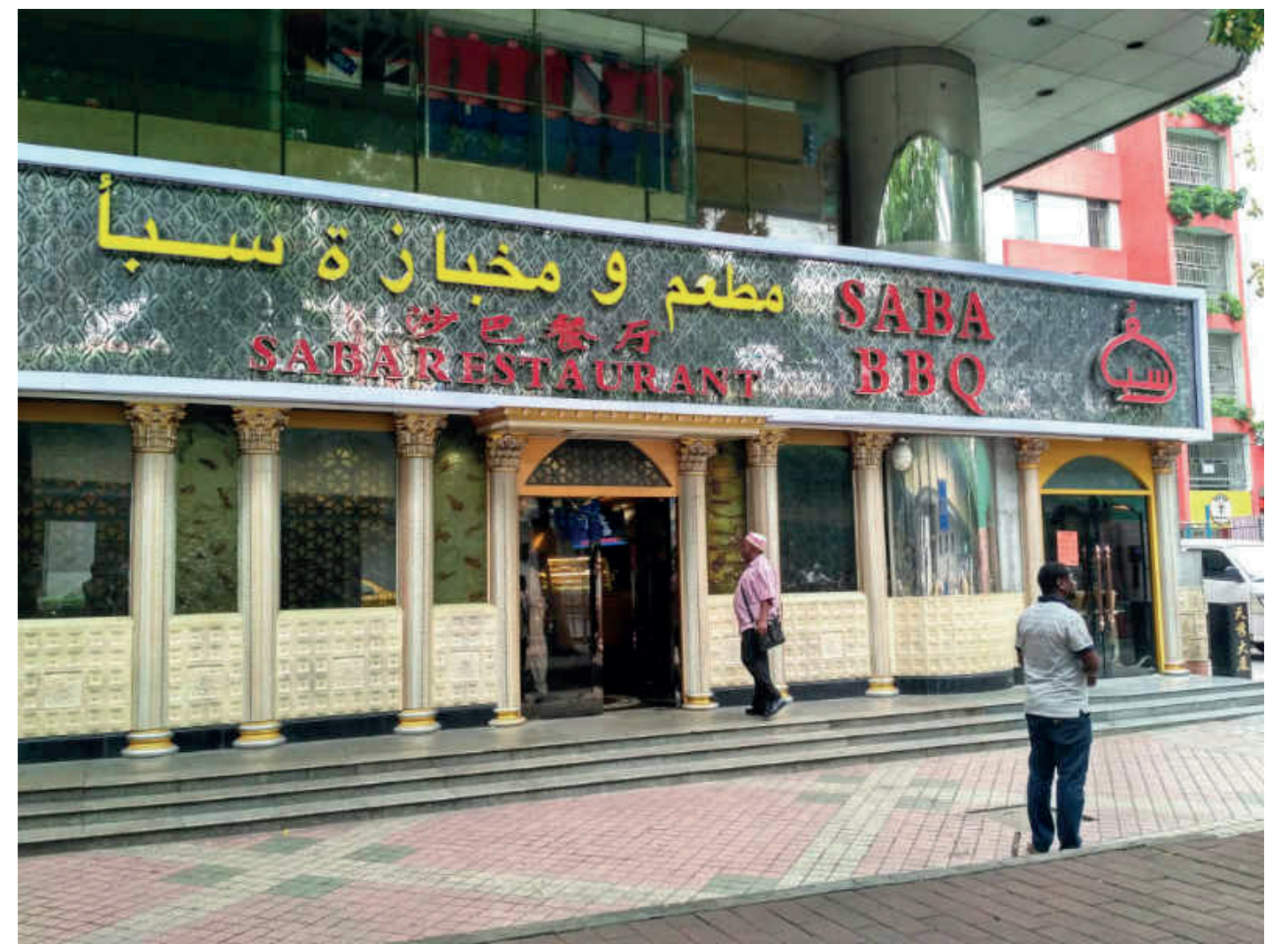

Figure 5: Halal restaurant at the junction of Xiaobeilu and Huanshizhonglu. (C) Ping Su)

To cater to Muslims' needs, many halal restaurants have been opened in Guangzhou, offering various cuisines. These restaurants - the owners, staff, and customers of which are quite often Muslims - are not simply eating places but are also hubs of belonging that gather together different Muslims: 
All the staff at our restaurant are Muslims. We usually perform our five daily prayers and regularly study Islamic knowledge together in the restaurant. During Ramadan, many Muslim customers of different nationalities will come to our restaurant to break the fast at sunset and then perform Maghrib prayer together. On Muslim festivals, the staff of some nearby halal restaurants will come to perform prayers with us as well. (Excerpt from a personal conversation with Ms. Lu, an employee at Saba Restaurant, on the first floor of the Tianxiu Building in the Xiaobeilu neighbourhood, conducted on 03 September 2015.)

This conversation also shows that contacts and interactions exist among different halal restaurants in the same neighbourhood, which is not the case among non-Muslim restaurants. Xiaobeilu has the greatest number and variety of Muslim restaurants in Guangzhou, selling African, Arabian, Turkish, Xinjiang, and Lanzhou food, as well as many other cuisines. All of these restaurants are frequented by Muslims of different ethnicities, forming another contact zone for the floating community of Muslims in the city. In addition, there are halal restaurants on the campuses of many of Guangzhou's colleges and universities, providing spaces for Muslim students from different countries to communicate and share information with each other.

Besides the real-life community, Guangzhou has a virtual community of Muslims as well. It is an online forum called Guangmushequ (Guangzhou Muslim Communityhttp://www.2muslim.com/forum.php?mod=forumdisplay\&fid=4), the members of which are mostly young Muslims who interact online and seek to construct a shared identity based on their religion. In addition to online communication, they arrange various activities offline, such as sports games, picnics, banquets, trips, and courses or lectures about Islam, the participants of which include both Chinese and foreign Muslims. Many members, after taking part in these activities, become friends in real life, with the result that this online forum now extends beyond the virtual space. It further breaks the geographical boundaries of the conventional community while strengthening the sense of connection and belonging for its Muslim members.

\section{Conclusion}

The Muslim community of Guangzhou, influenced by the city's long history as a trading port, is still shaped by its island spatiality today. Benefits of island spatiality-mainly territorial and transport benefits - along with the Chinese government's policy support, have led to the rapid development of the city's foreign trade and its further urbanization, which has in turn resulted in the revival of its Muslim community by attracting both international and domestic Muslim migrants to the city. Yet although Guangzhou's extreme urban density (conditioned by its island spatiality) has given rise to further agglomeration effects, it also functions as an internal dispersion force, changing Muslims' conventional residential patterns of concentration around mosques and incentivizing choice of residence on the basis of price or convenience for work. The Muslim community of Guangzhou is dispersed throughout the city, but it still exhibits solidarity. In this community, mosques, Muslim markets, shops, companies, restaurants, and websites provide space in which Muslims of different national origins and ethnic backgrounds, living separately in different parts of the city, can interact and communicate, thus creating a bond between them. In other words, the Muslim community of Guangzhou, extending beyond localized face-to-face interactions, is a floating community without fixed geographical, racial, ethnic, or national boundaries. 


\section{References (English)}

Anderson, B. (1991). Imagined communities: Reflections on the origin and spread of nationalism. London: Verso.

Baldacchino, G. (2012). The lure of the island: A spatial analysis of power relations. Journal of Marine and Island Cultures, 1(2), 55-62.https://doi.org/10.1016/j.imic.2012.11.003

Clark, D.B. (1977). Basic communities: Towards an alternative society. London: The Society for Promoting Christian Knowledge.

Coleman, J.S. (1976). Community disorganization and urban problems. In R.E. Merton \& R. Nisbet (Eds.) Contemporary social problems (pp. 559-601). New York: Harcourt Brace Jovanovich.

Gladney, D.C. (1996). Muslim Chinese: Ethnic nationalism in the People's Republic. Cambridge, MA: Harvard University Press.

Grydehøj, A. (2015). Island city formation and urban island studies. Area, 47(4), 429-435. https://doi.org/10.1111/area.12207

Grydehøj, A. (2014). Understanding island cities. Island Studies Journal, 9(2), 183-190.

Grydehøj, A., Pinya, X.B., Cooke, G., Doratli, N., Elewa, A., Kelman, I., Pugh, J., Schick, L., \& Swaminathan, R. (2015). Returning from the horizon: Introducing urban island studies. Urban Island Studies, 1, 1-19.https://doi.org/10.20958/uis.2015.1

Hayward, P. (2012). Aquapelagos and aquapelagic assemblages: Towards an integrated study of island societies and marine environments. Shima, 6(1), 1-11.

Jian, Z., \& Ma, R. (2011). Indigenization of imported religions in China: The case of Islam and the Hui people. In F. Yang \& J. Tamney (Eds.) Confucianism and spiritual traditions in modern China and beyond (pp. 201-228). Leiden: Brill.

Leslie, D.D. (1998). The integration of religious minorities in China: The case of Chinese Muslims. The Fifth-ninth George Earnest Morrison Lecture in Ethnology. Canberra: Australian National University. Available at: http://chinainstitute.anu.edu.au/sites/default/files/morrison59.pdf.

Lipman, J.N. (1997). Familiar strangers: A history of Muslims in northwest China. Seattle, WA: University of Washington Press.

Peck, M.S. (1988). The different drum. London: Rider.

Ronström, O. (2012). Finding their place: Islands as locus and focus. Cultural Geographies, 20(2), 153-165. https://doi.org/10.1177/1474474012445446

Roy, D. (1998). China's foreign relations. Lanham, MD: Rowman \& Littlefield. https://doi.org/10.1007/978-1-349-26364-6

Swaminathan, R. (2015). Ports and digital ports: The narrative construction and social imaginaries of the island city of Mumbai. Urban Island Studies, 1, 35-54. https://doi.org/10.20958/uis.2015.3

Wang, G., \& Zheng, Y. (2013). China: Development and governance. Singapore: World Scientific. https://doi.org/10.1002/9781118653784.ch8

Wellman, B. (1979). The community question: The intimate networks of East Yorkers. The American Journal of Sociology, 84(5), 1201-1231. https://doi.org/10.1086/226906

\section{References (Chinese)}

蔡穗声.广州历史文化名城探究 [J]. 热带地理, 1991, （1）：1-7. 高惠冰.广州成为中国近代民主革命策源地之历史渊源 $[J]$. 岭南文史，2006，（1）：21-26.

广东省民族宗教事务委员会. 广州市伊斯兰教协会四项举措强化资金管理效能 [EB/OL]. http://www. mzz jw. gd. gov. cn/view. aspx?id=8846, 2016-06-30/2016-0729. 
广东省文物局编. 广东文化遗产- - 海上丝绸之路史迹 [M]. 广州: 中山大学出版社, 2016.

广州市来穗人员服务管理局. 泛珠三角地区代表共商服务来穗人员新举措

[EB/OL]. http://1sj. gz. gov. cn/1snew/gzdt/201504/993d902d46aa46fba2fd6c79 f04c2893. shtm1, 2015-04-15/2016-07-19.

广州市来穗人员服务管理局. 广州市创新治理方式促新老广州人融合 [EB/OL]. http://1s

j. gz. gov. cn/1snew/gzdt/201606/e20b6d9fcc0e4cc392189b0ccf1469de. shtm1, 2 016-06-25/2016-07-28.

李荣珍. 永远的普哈丁 $[\mathrm{J}]$. 回族文学, 2006, (3) : 34-36.

李兴华.广州伊斯兰教研究（上） $[J]$. 回族研究，2011，（1）：69-85.

李兴华, 冯今源, 秦惠彬, 沙秋真. 中国伊斯兰教史 [M]. 北京: 中国社会科学出版社, 1998.

马苏第著. 耿昇译. 黄金草原 [M]. 西宁: 青海人民出版社，1998.

穆根来，汶江，黄倬汉译. 中国印度见闻录 [M]. 北京: 中华书局， 1983.

杨鹤书.广东各族人民宗教信仰的源流概况 [J]. 广州研究， 1986，(4)：52-55.

杨万秀，钟卓安.广州简史 [M].广州: 广东人民出版社， 2015 .

张难生，叶显恩. 海上丝绸之路与广州 [J]. 中国社会科学，1992，(1)：207-223.

郑大华. 中国近代民族主义与中华民族自我意识的觉醒 $[J]$. 民族研究，2013，（3）：114.

郑师渠. 近代中国的文化民族主义 [J]. 历史研究，1995，（5）：88-101. 